\title{
MESSAGE FROM OUR PRESIDENT
}

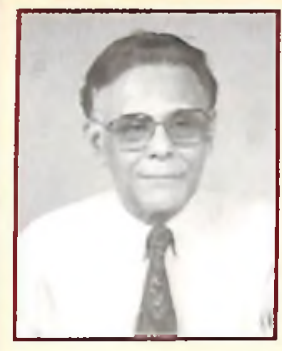

Dear Friends,

Given the national objective of making India a Knowledge Superpower by 2020, there is an urgent need for knowledge and skills capacity building. The challenges before us are to enhance the intellectual capital of our country to become a global leader in knowledge led manufacturing and service industries.

The current pace of economic growth in India is fast outstripping the supply of qualified professionals. The available talent pool is actually smaller than it seems, partly because of skill mismatches, but mainly because sheer numbers do not equal high quality, thereby adversely impacting our competitiveness.

While India at present has the advantage of having the first position for availability of scientists and engineers (Source : Global IT Report 2005-06 of the WEF), many of them have poor employability potential. Among the major shortcomings are poor communications and inadequate knowledge.

India will not be able to take advantage of demographic profile, if the youth do not receive relevant and quality education and training. Industry also suffers, as they are unable to find the required skilled manpower and have to expend huge resources to train and retain employees.

I would therefore, suggest to all our youngsters to join IIW, and qualify for AM-IIW Examination held twice in a year and get updated in the Welding Technology for higher prospects.

With all my best wishes,

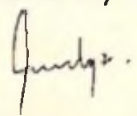

A. K. Mukherjee, President - IIW

Email : akmukherjee@techno.co.in

\section{HONY. SECRETARY GENERAL'S DESK}

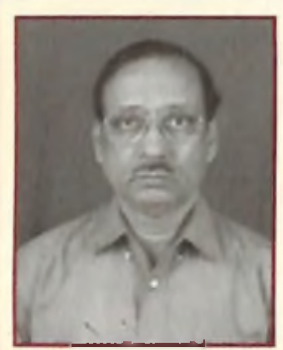

Dear Members,

You are aware that this year National Welding Meet (NWM-2006) will be held on $2^{\text {nd }}$ September'06 and is being organized by our IIW Baroda Branch. I, on behalf of Central Council, request all the members to participate in the NWM by contributing papers \& registering as delegates.

You are also aware that IIW Chennai Branch is organizing National Welding Seminar (NWS 2006) and "Weld India 2006" the International Welding Exhibition (Weld India 2006) during $24^{\text {th }}$ to $26^{\text {th }}$ November'2006 at Chennai. The theme of the NWS - 2006 is "Advances in Joining Technology for Quality \& Competitiveness". All members are requested to extend their help to make this event successful.

IIW Central Council decided to award International Welding Congress 2008 to Chennai Branch which will be held from $8^{\text {th }}$ to 10 th January 2008 at Chennai. The last International Welding Congress held in Mumbai was a grand success because all of us put our all out efforts for the same. Hence I would request all the Branches to extend all possible help to Chennai Branch to make this event a grand success.

The Annual General Meeting of our Institute will be held on $23^{\text {rd }}$ September 2006 at 5:00 p.m. at Park Hotel, Kolkata. I, on behalf of the Central Council, invite you all to attend the AGM.

We must thank all the Branch Managing Committees for holding their AGM in time which helped us to hold the AGM within the stipulated time.

There is no other option but to highlighting the need of increasing the strength of our membership. Branches need to take special drive to enroll new members as well as to organise renewal of our existing members.

Welding professionals are taking interest for acquiring IIW degree. A large number of Diploma Engineers who are working as trainees are approaching us. Branches need to take initiative to approach Automobile Industries, Railway Workshops for enrollment of students for AMIIW Examination.

Once again I invite you all to the Annual General Meeting \& looking forward to meet you in the AGM.

With warm regards

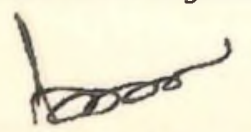

Parimal Biswas, Hony. Secretary General

Email : ewi@vsnl.net 